Archived version from NCDOCKS Institutional Repository http://libres.uncg.edu/ir/asu/

\title{
Appalachľan
}

B O O N E, N O R T H C A R O L I N A

\section{Hot, Salty Water: A Confluence Of Issues In Managing Stormwater Runoff For Urban Streams}

\author{
By: Kristan Cockerill, William P. Anderson, Jr., F. Claire Harris, and Kelli Straka
}

\begin{abstract}
Research increasingly highlights cause and effect relationships between urbanization and stream conditions are complex and highly variable across physical and biological regions. Research also demonstrates stormwater runoff is a key causal agent in altering stream conditions in urban settings. More specifically, ther- mal pollution and high salt levels are two consequences of urbanization and subsequent runoff. This study describes a demonstration model populated with data from a high gradient headwaters stream. The model was designed to explain surface water-groundwater dynamics related to salinity and thermal pollution. Modeled sce- narios show long-term additive impacts from salt application and suggest reducing flow rates, as stormwater management practices are typically designed to do, have the potential to greatly reduce salt concentrations and simultaneously reduce thermal pollution. This demonstration model offers planners and managers reason to be confident that stormwater management efforts can have positive impacts.
\end{abstract}

Cockerill, Kristan, William P. Anderson, Jr., F. Claire Harris, and Kelli Straka, 2017. Hot, Salty Water: A Confluence of Issues in Managing Stormwater Runoff for Urban Streams. Journal of the American Water Resources Association (JAWRA) 53(3):707-724. DOI: 10.1111/1752-1688.12528. Publisher version of record available at: https:/onlinelibrary.wiley.com/doi/epdf/10.1111/1752-1688.12528 


\title{
HOT, SALTY WATER: A CONFLUENCE OF ISSUES IN MANAGING STORMWATER RUNOFF FOR URBAN STREAMS
}

\author{
Kristan Cockerill, William P. Anderson, Jr., F. Claire Harris, and Kelli Straka
}

\begin{abstract}
Research increasingly highlights cause and effect relationships between urbanization and stream conditions are complex and highly variable across physical and biological regions. Research also demonstrates stormwater runoff is a key causal agent in altering stream conditions in urban settings. More specifically, thermal pollution and high salt levels are two consequences of urbanization and subsequent runoff. This study describes a demonstration model populated with data from a high gradient headwaters stream. The model was designed to explain surface water-groundwater dynamics related to salinity and thermal pollution. Modeled scenarios show long-term additive impacts from salt application and suggest reducing flow rates, as stormwater management practices are typically designed to do, have the potential to greatly reduce salt concentrations and simultaneously reduce thermal pollution. This demonstration model offers planners and managers reason to be confident that stormwater management efforts can have positive impacts.
\end{abstract}

(KEY TERMS: runoff; temperature; salinity; urbanization; urban stream syndrome; groundwater modeling; stormwater management.)

\section{INTRODUCTION}

The idea of "urban stream syndrome" has become a focal point for assessing and managing stream conditions in urban areas (Meyer et al., 2005; Walsh et al., 2005). Syndrome symptoms include stream flashiness, elevated nutrients/contaminants/temperature, altered channel morphology, and/or altered biotic assemblages. Causes are summarized as complex and interactive and not well understood (Wenger et al., 2009). Since the idea of urban stream syndrome was first introduced, it has become increasingly apparent that there are no definitive traits that consistently describe how urban development affects streams. For example, while flashiness is a common trait of urban streams, it is not universal (Ramirez et al., 2009). Water chemistry impacts are highly variable and depend on differences in physical and biologic conditions as well as historic and current land use (Walsh et al., 2005). For example, Brown et al. (2009) found land urbanized from agriculture showed no detectable changes in water quality or biota, likely because agriculture had already altered the stream system. Urbanization by itself does not consistently affect baseflow (Walsh

\footnotetext{
${ }^{2}$ Associate Professor (Cockerill) Interdisciplinary Studies, and Professor and Chair (Anderson), Department of Geology, Appalachian State University, ASU Box 32080, Boone, North Carolina 28608; Graduate Student (Harris), Department of Geography/Geology, Illinois State University, Normal, Illinois 61790; and Graduate Student (Straka), School of Earth and Climate Sciences, University of Maine, Orono, Maine 04469 (E-Mail/Cockerill: cockerillkm@appstate.edu).
} 
et al., 2005; O'Driscoll et al., 2010). Rather, baseflow in urban streams is complex and hence difficult to generalize (O'Driscoll et al., 2010; Price, 2011; Hamel et al., 2013; Liu et al., 2013). As Fitzgerald et al. (2012) documented, impacts from urbanization are not uniform at various gradients or various scales. They showed that higher-gradient streams are more susceptible to negative impacts from urbanizing and that the influence of urbanization on stream conditions declined when land cover and subsequent impacts were assessed at smaller spatial scales within a watershed. In short, impacts from urbanization vary across different physical and biological regions (Brown et al., 2009; Coles et al., 2012). Given the diversity in findings across multiple regions and scales in the citations presented here, studies further exploring the effects of urbanization and subsequent ideas about urban stream syndrome are warranted.

While the impacts from urbanization vary, the existing literature agrees that stormwater runoff is a key causal agent altering urban waterways. Runoff can contribute to increased discharge and thermal pollution, which is problematic for aquatic life (Caissie, 2003; USEPA, 2003; Jones et al., 2012; Wardynski et al., 2013). Researchers have examined the phenomenon of temperature surges, the process whereby heated runoff from urban environments quickly enters a stream and rapidly raises stream temperatures (Nelson and Palmer, 2007; Anderson et al., 2011). Temperature surges are especially relevant to understanding urban stream syndrome in cold water habitats. Several studies have examined these effects finding that stream temperatures and level of urbanization negatively influence cold water stream macroinvertebrate and fish populations (Wang and Kanehl, 2003; Wang et al., 2003). More specifically, cold water fish like trout and salmon exhibit stress when water temperatures are elevated (Quigley and Hinch, 2006; Chadwick et al., 2015).

Impervious surfaces are strongly correlated with runoff and subsequent negative impacts on urban streams including raising temperatures. Further, in cold climates, road salt is increasingly recognized as a runoff issue affecting both surface and groundwater (Kaushal et al., 2005; Brown et al., 2009; Daley et al., 2009; Wenger et al., 2009; Cooper et al., 2014; Halstead et al., 2014). Runoff research, however, demonstrates that assessing urbanized streams requires more than simply calculating total impervious surface area (Brabec et al., 2002; Booth et al., 2004; Burns et al., 2015). Studies suggest that where impervious surfaces are located within a watershed (Brabec et al., 2002) and how runoff is managed (Burns et al., 2015) are more relevant than the total amount of impervious surface. Reviews of urban stream ecology, therefore, argue against attempts to provide uniform thresholds of any kind, including an impervious surface threshold (Brabec et al., 2002; Wenger et al., 2009). As a whole, the body of knowledge about urban streams indicates that assessing, managing, and potentially remediating urban stream syndrome requires thinking at a watershed scale, addressing causes rather than symptoms, and integrating social, economic, and ecological factors specific to a given locale (Booth et al., 2004; Wenger et al., 2009; Yocom, 2014).

The relevance of watershed character and conditions to individual stream conditions has been long established. Yet, attention to watershed scale planning and management and more specifically, attention to stormwater runoff management, has lagged. There are signs that this is shifting since the idea of "urban stream syndrome" was introduced. For example, the United States (U.S.) Environmental Protection Agency (USEPA) now emphasizes watershed health as key to ensuring overall water quality (USEPA, Healthy Watersheds: Protecting Aquatic Systems through Landscape Approaches, https://19janua ry2017snapshot.epa.gov/hwp_.html). Despite this recent shift in attention, watershed scale management remains difficult and is the exception rather than the rule. Most urban stream management, including remediation, remains focused on "instream" efforts rather than being applied at the watershed scale. This has reduced the effectiveness of employed measures (Christian-Smith and Merenlender, 2010; Palmer et al., 2010; Sudduth et al., 2011; Violin et al., 2011; Smith et al., 2013; Wohl et al., 2015). Such findings are not surprising given the growing body of work showing runoff as a key cause of urban stream impairment. No "in-stream" measure will adequately address the problem if the root cause is runoff from throughout the watershed.

To address stormwater runoff concerns, researchers have proposed Low Impact Development (LID) techniques. LID effectiveness is variable and locale specific. For example, Loperfido et al. (2014) found different levels of effectiveness in comparing distributed and centralized stormwater management techniques under low vs. high water conditions. Ahiablame et al. (2012) reviewed LID research highlighting variability for different techniques and concluded there is a need for more watershed scale assessments, and that implementing LID practices remains a challenge. More specifically, they found that bioretention, swales, and permeable pavement can reduce stormwater runoff impacts if designed, installed, and maintained appropriately for their location. The studies they reviewed on green roofs, however, showed mixed results, including potentially increasing nutrient levels in runoff. Their review did not include salt as an LID concern. Other studies have found that 
bioretention does not retain salt (Khan et al., 2012; Soberg et al., 2014); that salt in bioretention systems increases heavy metal release (Soberg et al., 2014); and that salt affects bacterial communities subsequently affecting the uptake potential in a bioretention system (Endreny et al., 2012). Further, studies have shown salt use within a watershed can be a chronic issue for both surface and groundwater and is not limited to winter conditions (Perera et al., 2013; Corsi et al., 2015).

In the Second Symposium on Urbanization and Stream Ecology, Wenger et al. (2009) identified a series of research questions about urban stream syndrome and one of the emphasis areas was to better understand how stream stressors covary. Our study builds on the existing body of work by employing demonstration models to study surface water-groundwater interactions as well as temperature surges and salinity spikes. This project focuses on three research questions:

1. What specific mechanisms might explain high salt levels in streams in the summer?

2. Is eliminating salt application the only way to reduce chronic/acute salt levels in streams?

3. Can reducing quickflow decrease chronic and/or acute salt levels and/or temperature surges in streams?

\section{STUDY AREA}

Boone Creek is a headwaters tributary of the South Fork New River, which drains a portion of the Blue Ridge Mountains in northwestern North Carolina. This stream is designated as a trout stream in North Carolina, meaning it has historically had trout and could potentially support stocked trout year-round (NCDEQ, 2016). Although the stream lies in a mountainous region with a total relief of nearly $500 \mathrm{~m}$, the stream has only a moderate gradient that averages approximately $2 \%$. There are several nonurbanized tributaries, however, that have gradients of approximately $20 \%$. The catchment of the section of Boone Creek relevant to this study has an area of approximately $5.2 \mathrm{~km}^{2}$.

The primary aquifer system in the region is fractured bedrock (see Wang et al., 2014; for the hydraulic characteristics of one of the units comprising the bedrock within the catchment). The primary bedrock unit in the watershed is the felsic Cranberry Gneiss, although the upper portions of the tributaries near the northern drainage divide comprise the amphibolite of the Ashe Metamorphic Suite (North Carolina Geological Survey, 1985). Alluvial sediments form narrow surficial aquifers along the main stem of Boone Creek and larger tributaries; otherwise, the bedrock aquifers have limited surficial sedimentary cover. Regional groundwater flow is primarily through these fractured bedrock systems, with the alluvial sediments being the primary zone of interaction with the stream. There is not a salt source outside of the urban area of the watershed (North Carolina Geological Survey, 1985); therefore, all salt occurring within the catchment must be attributed to anthropogenic sources.

The $1.8 \mathrm{~km}$ reach of Boone Creek discussed here flows through the Town of Boone which has a population of approximately 18,000 (U.S. Census Bureau, Quick Facts, https:/www.census.gov/quickfacts/table/ PST045216/3707080,00) and Appalachian State University (ASU) with a student population of approximately 18,000 (www.appstate.edu/about) and is heavily urbanized (Figure 1). Rice et al. (2011) delineated the Boone Creek catchment used in this study with the ArcHydro extension of ArcGIS v9.4 combined with a $3-\mathrm{m}$ resolution, LIDAR-generated digital elevation model from 2008. They differentiated between impervious and pervious surfaces, using stock ArcGIS tools combined with a $15-\mathrm{cm}$ resolution true-color, orthorectified aerial photo taken in 2009. Their findings included that impervious surfaces make up approximately $13.7 \%$ of the catchment area upstream of the temperature study site used in our article (Figure 1) and up to approximately $24.3 \%$ within the entire catchment (Figure 1). In the study area, the stream is routed through several culverts, including one that is approximately $600 \mathrm{~m}$ long.

In 2006 Anderson and colleagues began assessing conditions on Boone Creek and found that it exhibits characteristics of the urban stream syndrome. Consistent monitoring since 2006 has revealed that the stream is extremely flashy, sometimes increasing stream discharge by two orders of magnitude during storm events based on rating curves (Anderson et al., 2007, 2010). Further, despite the relatively high elevation $(\sim 1,000 \mathrm{~m}$ above sea level), the stream experiences temperature surges and routinely exceeds temperatures suggested for trout habitat of $20^{\circ} \mathrm{C}$ (Anderson et al., 2011). Additionally, electrical conductivity levels sometimes exceed water-quality standards by a factor of six (Anderson et al., 2007). A 2007 biological assessment gave the creek a "poor" rating on the North Carolina Index of Biological Integrity for macroinvertebrates (Thaxton and Cockerill, 2007).

\section{METHODS}

This study used existing data gathered from the stream monitoring effort implemented in 2006 to 


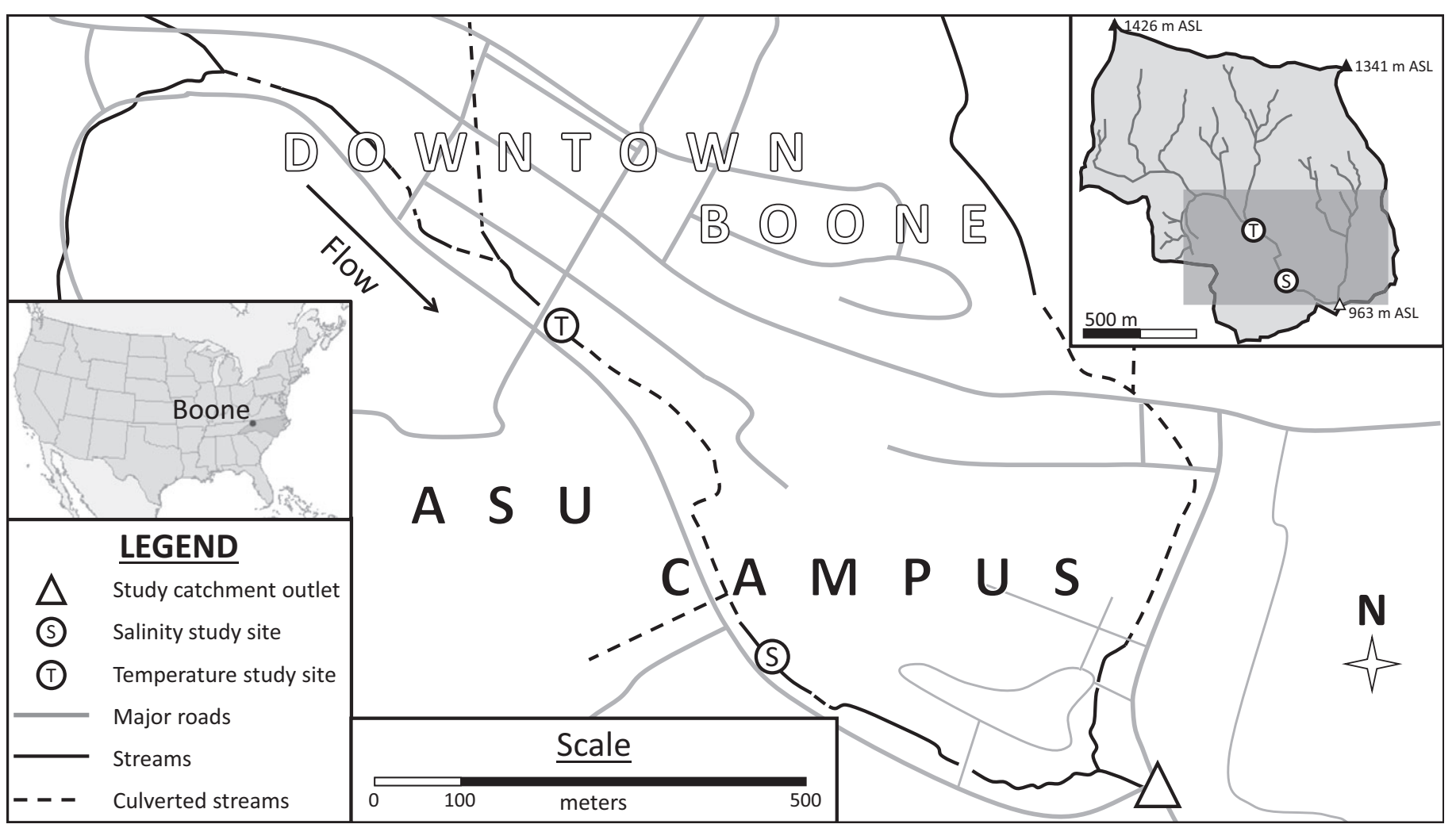

FIGURE 1. A Map Showing the Study Catchment Boundaries and the Specific Monitoring Sites for the Data Used to Populate the Demonstration Model. The black triangles in the inset map show peak elevations in the watershed.

frame a modeling project designed to answer our research questions. Since July 2014, a more intensive monitoring effort at two sites has provided detailed high-quality continuous time series of temperature, specific conductivity, and stage/stream discharge data. Assessing these data catalyzed this project to develop demonstration models to better understand the groundwater-surface water dynamics related to salt and temperature. Figure 1 shows the monitoring site locations for salinity and temperature within the study area. Figures 2 and 3 show the monitoring data used as boundary conditions in the demonstration models.

As part of the monitoring effort, pressure transducers installed in stilling wells at the two sites have measured water levels. Rating curves were established at both sites to convert stream stage to stream discharge. The rating curves were established using hand measurements with a SonTek Acoustic Doppler Velocimeter (Sontek/Xylem Inc., Rye Brook, New York) and with Manning's Equation calculations that have been calibrated based on parameters measured at both sites. These data drive our calculations of stream-groundwater interactions. Specific conductivity measurements at the salinity study site were collected with a HOBO Fresh Water Conductivity Data Logger U24-001 (Onset Computer Corp., Bourne,
Massachusetts). Temperature measurements at the temperature study site were collected with a HOBO Water Temperature Pro v2 datalogger (Onset Computer Corp.). All data were measured every $15 \mathrm{~min}$. Both the temperature and electrical conductivity dataloggers were suspended in the water column and tethered with climbing rope to metal anchors secured within the streambed. The temperature dataloggers have a natural buoyancy and so are secured such that the temperature sensor was well below the stream level. The electrical conductivity dataloggers, however, were not buoyant but were made so with pipe insulation, which is secured to the devices well above the sensor. In this manner, the probes floated in the water column in a similar manner to the temperature dataloggers. Author Anderson has successfully employed these methods to make the dataloggers stable in this highly dynamic environment.

\section{Calculation of Equivalent Chloride Values}

Unlike the stream temperature data, which required little processing, the electrical conductivity data required multiple processing steps. First, we applied a correction to the data to a specific 


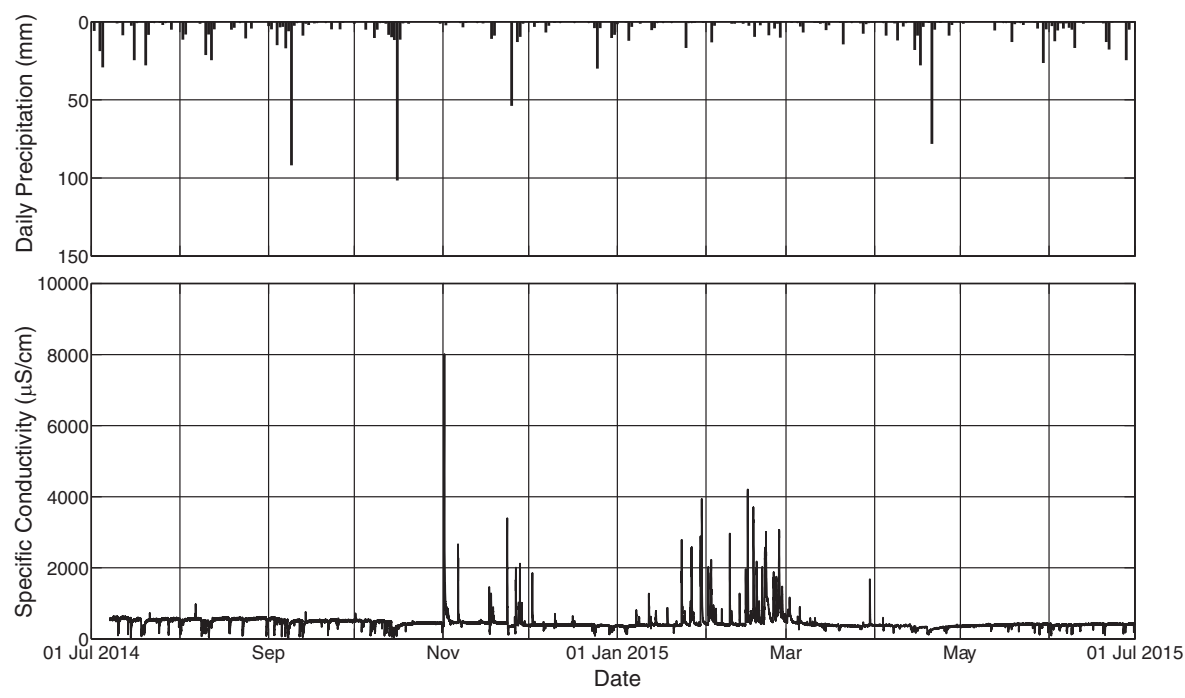

FIGURE 2. Full Time Series of Daily Precipitation Totals (upper panel) and Specific Conductivity at the Salinity Monitoring Site (lower panel) from July 1, 2014 to July 1, 2015.

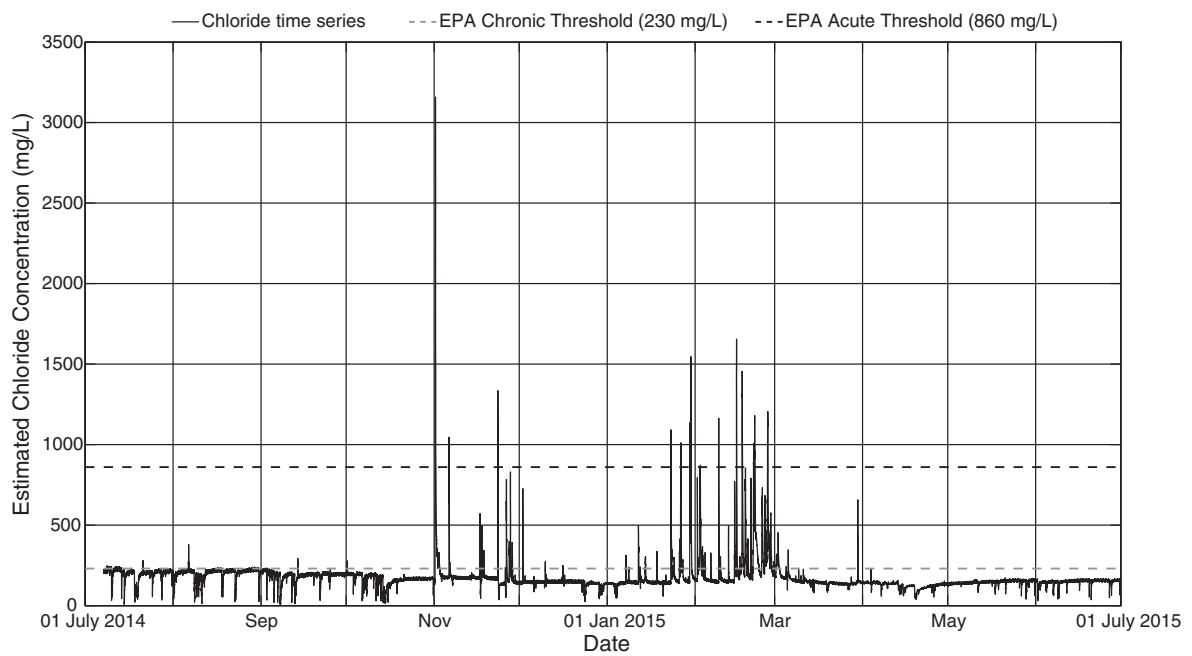

FIGURE 3. Full Time Series of Calculated Chloride Levels (black lines) from the Salinity Monitoring Site between July 1, 2014 and July 1, 2015. Also shown are the chronic chloride exceedance thresholds (gray dashed line) and acute chloride exceedance thresholds (black dashed line). These exceedances relate to EPA guidance levels of 230 and $860 \mathrm{mg} / \mathrm{L}$, respectively.

conductivity at $25^{\circ} \mathrm{C}$ based on Fofonoff and Millard (1983). Second, there was a tendency in the electrical conductivity data for calibration drift. To counter this, we hand measured specific conductivity values with a Yellow Springs Instruments, Inc. (Yellow Springs, Ohio) YSI 556 Multiparameter System probe at each site at the time of each data download, which occurred every two to four weeks. We then applied a drift correction as a linearly interpolated adjustment to the downloaded dataset in the manner of Perera et al. (2010). Finally, we applied a conversion of the specific conductivity data to an equivalent chloride concentration in units of $\mathrm{mg} / \mathrm{L}$. The literature provides several methods that utilize measured relationships between lab measured specific conductivity and chloride concentrations (see Perera et al., 2010; Conrads et al., 2011). For our field-based sampling, we used the relationship provided by Windsor et al. (2011) as a general approximation of the relationship using the equation

$$
C_{\mathrm{Cl}}=0.3946 \mathrm{SC}-7.065\left(C_{\mathrm{Cl}}<2,000 \mathrm{mg} / \mathrm{L}\right),
$$

where $C_{\mathrm{Cl}}$ is the concentration of chloride $(\mathrm{mg} / \mathrm{L})$ and $\mathrm{SC}$ is the specific conductivity at $25^{\circ} \mathrm{C}(\mu \mathrm{S} / \mathrm{cm})$. As only 10 of our data points rise above $2,000 \mathrm{mg} / \mathrm{L}$, we think using this equation is satisfactory.

The calculated chloride concentrations at the salinity field station were then used to calculate chronic and acute chloride levels as defined by the USEPA 
(1988) and mentioned in other road salt studies (Kaushal et al., 2005; Cooper et al., 2014). Although not regulated, USEPA has recommended these levels as standards to ensure aquatic organism health. Chronic chloride levels are reached at a four-day moving window average concentration of $230 \mathrm{mg} / \mathrm{L}$, while acute levels occur at a one-hour average of $860 \mathrm{mg} / \mathrm{L}$. We applied the method of Fofonoff and Millard (1983) to perform a conversion of specific conductivity to salinity, which was necessary for groundwater flow and solute transport simulations.

Figure 2 shows a time series of specific conductivity as measured at the salinity field site. It should be noted that these data were collected during a relatively mild winter with no snow or ice during all of December and half of January. Two items are of particular interest: (1) the "salt season" between November 1, 2014 and March 31, 2015, when specific conductivity levels peak above $8,000 \mu \mathrm{S} / \mathrm{cm}$ and reach levels of $2,000-4,000 \mu \mathrm{S} / \mathrm{cm}$ for a one and a half-month stretch in January and February, and (2) the dilution events that occur throughout the time series. The dilution events are informative because they occurred during rain events, when freshwater runoff from the basin diluted the baseflow conductivities that had been stored during storm events. This also suggests the chronic nature of saline contamination of the riparian aquifer along Boone Creek.

Figure 3 shows an estimated chloride time series based on the measured specific conductivity levels shown in Figure 2. Dilution events are readily apparent. Also shown in Figure 3 are chronic and acute chloride exceedance thresholds based on the EPA chloride standards (USEPA, 1988) and the chloride levels that define those standards. The calculated chloride concentrations demonstrate that during the year of data, chloride levels reached the chronic threshold nearly $10 \%$ of the time or nearly 36 days. Comparisons with previous data show increasing chloride concentrations over the past decade in Boone Creek (Cockerill and Anderson, 2014). Acute conditions occurred across the equivalent of nearly 8.5 days.

\section{Salt-Transport Modeling}

We used the specific conductivity monitoring data and the calculated salinity and chloride values described in Figures 2 and 3 to construct a numerical demonstration model of groundwater flow and solute transport using the finite-element model FEFLOW (DHI-WASY, DHI Group, Horsholm, Denmark). For examples of studies using FEFLOW, see Sarwar and Eggers (2006) and Yechieli et al. (2009). These simulations represent groundwater flow and transport conditions in a hypothetical two-dimensional cross section based on conditions measured at the salinity study site (Figure 4). The simulations are meant to demonstrate groundwater-surface-water interactions and salt transport in an urban stream setting. The simulations are not modeling specific conditions in the stream-aquifer system. Rather, they are being used as a numerical laboratory to demonstrate the likely pathway of salt into alluvial aquifers because of urban stream conditions: (1) flashiness, which frequently results in reversed gradients, and (2) saline runoff, which gets driven into streambanks because of those reversed gradients. These simulations question a common assumption that the salt source in saline contamination of aquifers is through recharge and topographically-driven flow to streams.

We simulated a fluctuating stream-level boundary condition at nodes corresponding to the stream based on stage data collected over the course of one year (July 1, 2014 through July 1, 2015). We combined these stage data with calculated salinities through that same time period. Figure 5 shows the time series that were used in the boundary conditions. We set these values as variable concentration data in the nodes corresponding to the stream bed, using a minimum mass-flow setting of $0 \mathrm{~g} /$ day. Inland from the stream at the left boundary of the model domain, we set constant-head nodes in order to produce a regional gradient of 0.001 under baseflow conditions and to allow bank storage to take place during storm events. Initial conditions in the model's aquifer include zero salinity and a gradient from the left boundary to the stream. Another study of the basin at the watershed scale demonstrates that the source of salt in the stream is from surface runoff, not regional flow, and is based on 50 years of salt application data for the Town of Boone (F.T. Shepherd, 2016, unpublished thesis); therefore, we think that the zero salinity initial condition is valid. Under base case conditions, the model is allowed to behave in response to fluctuating stream stages and salinity based on the data from the salinity monitoring site.

Because we only have one year of the combined, high-resolution salinity and stream stage data shown in Figure 5, we have repeated the storm and salinity boundary conditions for multiple years to simulate a longer period of road salt application. We think this is reasonable given (1) road salt application happens on a yearly basis and (2) the year of data we are using comes from a fairly mild winter; thus, our model estimates are at the conservative end of the spectrum. Given our demonstration goal, we did not calibrate this model with specific field data. However, the simulated baseflow salinities, vertical gradients in the streambed and simulated monitoring well data from locations adjacent to Boone Creek all compare 


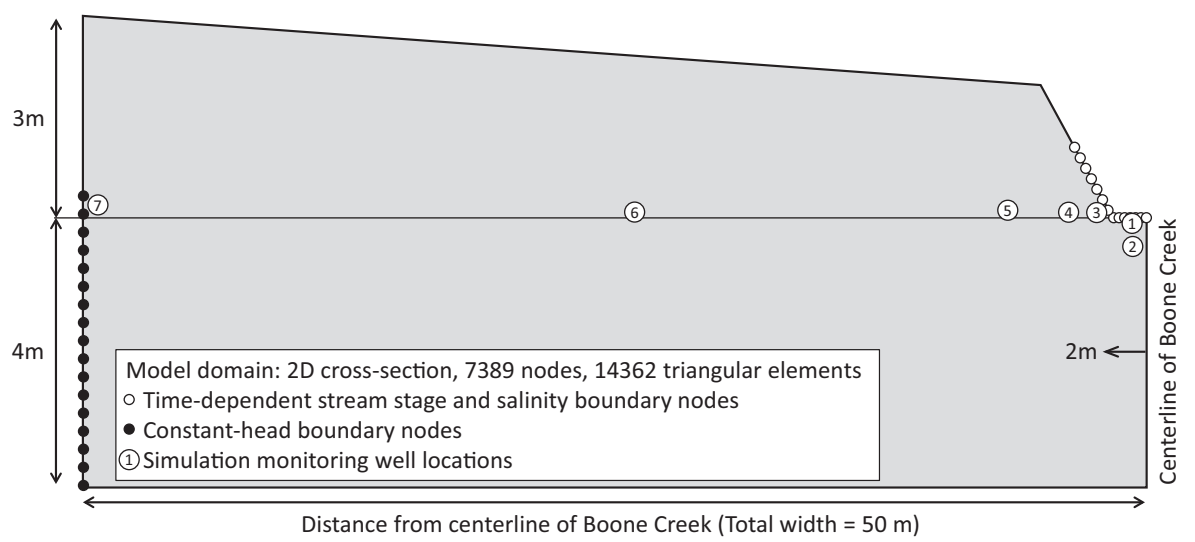

FIGURE 4. Two-Dimensional Cross-Section Model Domain for the Salt Transport Simulations Based on the Conditions at the Salinity Monitoring Site. The figure shows monitoring well and constant-head and time-dependent stream stage and salinity nodes.
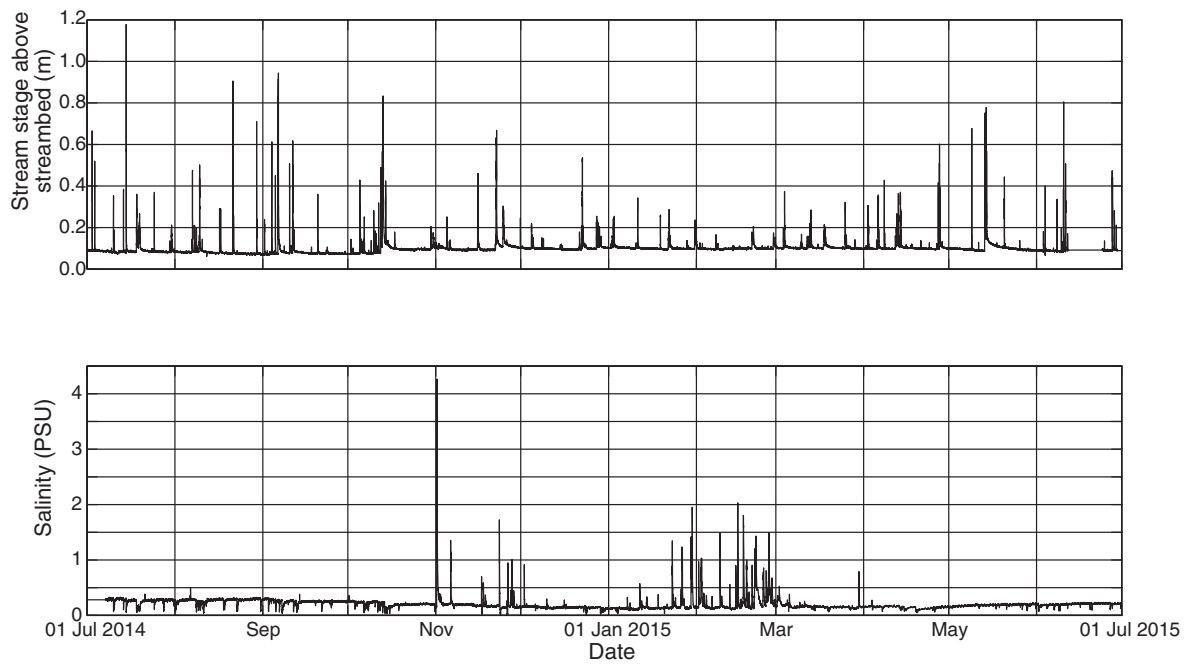

FIGURE 5. Time Series of the Stream Boundary Conditions in the Groundwater Flow and Solute Transport Model with Stream Stage (upper panel) and Stream Salinity (lower panel).

well with field measurements at the salinity site (W.P. Anderson, Jr., unpublished data).

In addition to the base case scenario, our test simulations looked at the response of salt transport into the aquifer under alternative scenarios. The most obvious option is to reduce salt application within the watershed: under this scenario, we reduced the chloride concentration boundary condition by half and model the effects of this reduction. A second test simulation explored the effect of keeping salt concentrations at base case conditions but reducing stage fluctuations by half to represent the effects of a generic stormwater management system. For all model scenarios, we ran the saline conditions for 5 years in order to salinate the aquifer, then ran 25 years of recovery simulations in which we removed all salt sources from the stream in order to look at salt residence time in the aquifer.
The simulations we developed are not intended to assess the ability of specific stormwater "best management practices" (BMPs) to achieve this stage reduction; instead, they looked at the effects that stage reductions have on the hydraulics of the system. Thus, the modeling effort questioned the assumption of a single, long-path salt transport and is being used to demonstrate the effects of urban stream syndrome on groundwater-surface-water interactions, especially those related to saline transport.

\section{Temperature-Surge Modeling}

As noted in the Introduction, quick changes in stream temperature have a strong effect on coldwater species; thus, we tested mitigating quickflow 
and its effectiveness with two energy-balance simulations of Boone Creek. These are simple mixing-model calculations in which we assumed that stormwater BMPs had been implemented to store heated runoff beyond the scope of the mixing model. We were not interested in the specific type of BMPs; rather, we were interested in the effects that quickflow reductions could have on peak stream temperatures that occur during temperature surge events. We defined a temperature surge as a rise of $>1{ }^{\circ} \mathrm{C}$ within $15 \mathrm{~min}$ (see Anderson et al., 2011), which is the level at which we monitored stream data. We identified surges in the dataset by looking at differences $>1^{\circ} \mathrm{C}$ between adjacent data points. Because we have discharge data and a nearly continuous time series at this location, we utilized data from the temperature monitoring site (Figure 1) lying at the middle of the $1.8 \mathrm{~km}$ monitored stream reach just before an approximately $600 \mathrm{~m}$-length culvert.

Figure 6 shows the temperature time series from the monitoring site, occurrences of temperature surge events, and the critical temperature for coldwater species. Although the upper panel of the figure shows 10 years of record, there are 2 years missing due to nonmeasurement $(2009,2011)$ and several short gaps (Autumn 2010, June 2012, September 2013) due to lost equipment from flash floods. Of note in the upper panel is the fewer number of temperature surge events in the early years of monitoring, the few (three) events in 2008 during a very dry summer in the study region, and the general increase in the number of events and the maximum temperatures reached in the past few years. Overall, the data show 422 individual temperature surge events in the approximately eight complete years of record. Also of particular note are the surges during winter months in 2012, 2013, and 2015. The lower three panels of Figure 6 show data in detail for the complete years 2013, 2014, and 2015. Table 1 shows the number of surges by year, including the number of individual surge events that rose above the critical temperature of $20^{\circ} \mathrm{C}$ and the overall percentage of surge events that rose above this value.

We used a rating curve from the stream gauge at the temperature monitoring site to estimate stream discharge from measured stage data. These data suggest that stream discharge at the site rises up to two orders of magnitude during storm events. We used the local minimum method to separate baseflow from total stream discharge (Sloto and Crouse, 1996) using

$$
Q_{\text {baseflow }}=\min \left(Q_{i-N}: Q_{i+N}\right)
$$

where $Q$ is measured stream discharge and $N$ is the duration of surface water drainage that is calculated from the basin area using $N=A^{0.2}$, where $A$ is the watershed area in square miles. A moving window of duration $N$ is applied at the mid-point of the window to find the minimum occurring within that interval. We then calculated quickflow using a simple difference between stream discharge and calculated baseflow at each time step.

We also applied the local minimum filter with the stream temperature data to determine the stream temperature without the storm event. We applied this method only during the temperature surge events to approximate non-storm conditions. This
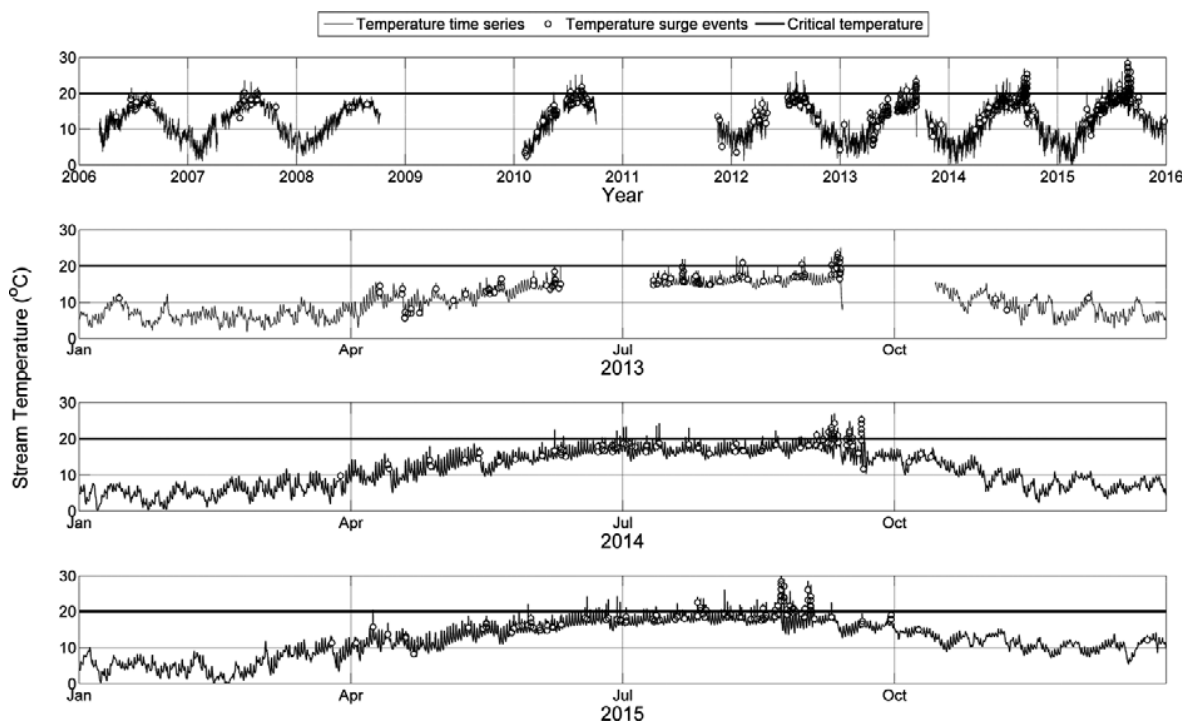

FIGURE 6. Full Time Series of Stream Temperature (upper panel) from Temperature Monitoring Site from 2013 (upper middle panel), 2014 (lower middle panel), and 2015 (lower panel). 
TABLE 1. Data on the Number of Temperature Surges at the Monitoring Site over the Course of Stream Monitoring.

\begin{tabular}{lccc}
\hline Year & $\begin{array}{c}\text { Number of Tem- } \\
\text { perature Surges }\end{array}$ & $\begin{array}{c}\text { Number of } \\
\text { Surges }>\mathbf{2 0} \mathbf{C}^{\circ} \mathbf{C}\end{array}$ & $\begin{array}{c}\text { Percentage of } \\
\text { Surges }>\mathbf{2 0} \mathbf{}^{\circ} \mathbf{C}\end{array}$ \\
\hline 2006 & 13 & 3 & 23 \\
2007 & 16 & 8 & 50 \\
2008 & 3 & 0 & 0 \\
2009 & - & - & - \\
2010 & $55^{*}$ & -22 & - \\
2011 & - & 16 & 39 \\
2012 & $41^{*}$ & 25 & 28 \\
2013 & $91^{*}$ & 42 & 47 \\
2014 & 89 & 66 & 60 \\
2015 & 111 & & \\
\hline
\end{tabular}

*Denotes a year lacking a full summer dataset.

non-storm stream temperature can be thought of as a mixing of waters that are influenced by baseflow and solar heating components. Because this water circulates during a dynamic mixing event, we think that this is the best approximation of baseflow temperatures.

During storm events, we assumed that the first quickflow arrives from the impervious surfaces and that this high-temperature water has a much larger effect on stream temperature than any atmospheric effects; therefore, we ignored atmospheric effects for the brief storm events. Using the filtered temperatures and discharge components, we developed an energy balance equation that, when rearranged, can be used to approximate quickflow temperatures using

$T_{\text {quickflow }}=\left(Q_{\text {stream }} T_{\text {stream }}-Q_{\text {baseflow }} T_{\text {nonstorm }}\right) / Q_{\text {quickflow }}$,

where $Q_{\text {stream }}$ is stream discharge at a stream temperature of $T_{\text {stream }}, Q_{\text {baseflow }}$ is the baseflow discharge calculated with the method of Sloto and Crouse (1996) and assumed to be discharging at a temperature of $T_{\text {non-storm, }}$ and the quickflow discharge calculated with a simple mass balance is $Q_{\text {quickflow. The }}$ solution of this equation gives the quickflow temperature, $T_{\text {quickflow. }}$.

We created two temperature reduction models that explore the effects of changes in quickflow volume and quickflow temperatures on stream conditions during temperature surges by altering Equation (3). Like the salinity simulations, we took a big picture approach to the simulations: we did not assess any specific BMPs, but rather assessed the effects that reduced quickflow could have on the magnitude of the temperature surges. We used Equation (3) as our base mixing model equation, but altered it for two scenarios: (1) simulations in which the impermeable surface coverage (ISC) percentage within the basin is reduced and the non-ISC percentage is increased while keeping quickflow rates the same, and (2) simulations in which quickflow rates are reduced while keeping quickflow temperature distributions the same.

In the first model, we explored the conversion of ISC to non-ISC by changing the distribution of quickflow temperatures. We based this on previous work in the basin, which estimated that the amount of ISC inside a $25-\mathrm{m}$ buffer zone along Boone Creek ranges from $1 \%$ to $75 \%$ (Rice et al., 2011). For these demonstration calculations, we assumed that $75 \%$ of the area within the buffer at the temperature monitoring site and upstream of the site is ISC and that the runoff creating the temperature surges comes directly from the $25-\mathrm{m}$ buffer zone or is piped in directly through culverts. Our forward model under this scenario, modified from Equation (3), becomes

$$
\begin{aligned}
T_{\text {stream }}= & \left(Q_{\text {baseflow }} T_{\text {nonstorm }}+Q_{\text {quickflow }}\right. \\
& *\left(\%_{\text {ISC }} \%_{\text {reduction }} T_{\text {quickflow }}\right. \\
& \left.\left.+\%_{\text {non-ISC }} \%_{\text {increase }} T_{\text {air }}\right)\right) / Q_{\text {stream }}
\end{aligned}
$$

where $T_{\text {quickflow }}$ has been calculated from Equation (3). The model in Equation (4) keeps all components of flow as they have been calculated from the field data, but changes the mixture of quickflow $\left(\%_{\text {reduction }}\right.$ in the equation) and air temperatures $\left(\%_{\text {increase }}\right.$ in the equation), thereby representing a hypothetical conversion from ISC to green space as a proxy for any stormwater management that reduces the rate of quickflow.

The air temperatures used in the model, $T_{\text {air }}$, were obtained from the North Carolina State Climate Office to estimate quickflow temperatures for the non-ISC surfaces based on the work of Herb et al. (2008). ISC quickflow temperatures were estimated from Equation (3) with field data. We separated the two sources of quickflow into relative contributions from ISC and non-ISC areas in terms of percentages (\%ISC and $\%_{\text {non-ISC }}$, respectively). At the temperature monitoring site, $\%_{\text {ISC }}$ was set to $75 \%$ and $\%_{\text {non-ISC }}$ was set to $25 \%$. To simulate reductions in the quickflow temperature due to potential stormwater storage practices in the watershed, we reduced the ISC and increased the non-ISC areas to examine the influence of ISC on temperature surge events. The ISC reductions were calculated in $10 \%$ increments, thereby showing the sensitivity of model output to ISC percentage within the zone of influence of the temperature surge.

In the second model, we calculated the effects of reducing the amount of heated quickflow volumes 
reaching the stream during temperature surge events using

$$
\begin{aligned}
T_{\text {stream }}= & \left(Q_{\text {baseflow }} T_{\text {nonstorm }}+Q_{\text {quickflow }} \%_{\text {reduction }}\right. \\
& \left.*\left(\%_{\text {ISC }} T_{\text {quickflow }}+\%_{\text {non-ISC }} T_{\text {air }}\right)\right) / Q_{\text {stream }}
\end{aligned}
$$

where $\%_{\text {reduction }}$ is now applied to $Q_{\text {quickflow }}$ Quickflow rates were incrementally reduced in Equation (5) to calculate stream temperatures under a variety of quickflow scenarios but with full quickflow temperatures as estimated in Equation (3). The goal of this model was to demonstrate the effects that reducing runoff may have on the magnitude of the temperature surges; its goal was not to assess specific stormwater BMPs.

\section{RESULTS}

\section{Salt-Transport Modeling}

Figure 7 shows salinity contours at the end of five years of stage fluctuations and stream salt source simulations for base case, half salt, and half stage simulations. The base case simulation utilized stream salinity and stage boundary conditions for five years of simulation. As the upper panel in Figure 7 shows, the reversed-gradients that occurred during stream stage increases caused temporary losing stream conditions and advect salt into the riparian aquifer. After five years of simulation time, groundwater at the edge of the aquifer exceeded salinities of 0.2 and the dimensions of the plume as defined by the 0.02 salinity level were approximately $9 \mathrm{~m}$ inland and $2 \mathrm{~m}$ below the center of the stream. The half salt simulations cut stream salinity boundary conditions in half. As expected, the maximum salinities rose just above 0.10 , but what is intriguing is that the plume dimensions also decreased to approximately $7.5 \mathrm{~m}$ inland and $1.5 \mathrm{~m}$ in depth below the stream. These decreases, despite simulating the same stream fluctuations, occurred because of lower density-driven flow with the lower salinities, especially during high streamflow events. Similar plume dimensions were encountered in the half stage simulations, which decreased storm events in the stream by a factor of two. Although the salt content of the stream water was the same as in the base case simulations, the lower energy of the reversed gradients kept the plume to the same approximate dimensions of the half salt simulations, although the peak concentrations showed salinities of up to 0.21 .

As an exercise to determine the residence time of the salt as generated from the saline stream boundary, simulations were continued for 25 years of additional simulation time without any salt in the stream. Figure 8 shows salinity distribution in the riparian aquifer for base case, half salt, and half stage simulations after 10 years of recovery. It is evident that the base case condition with full stream dynamics kept the salt in residence in the aquifer over a much wider distance than either the half salt or half stage condition based on the location of the 0.01 salinity contour. In fact, salinity values were elevated nearly $10 \mathrm{~m}$ into the aquifer in the base case condition. It should be noted, also, that the peak salinity values in each of the simulations lies above

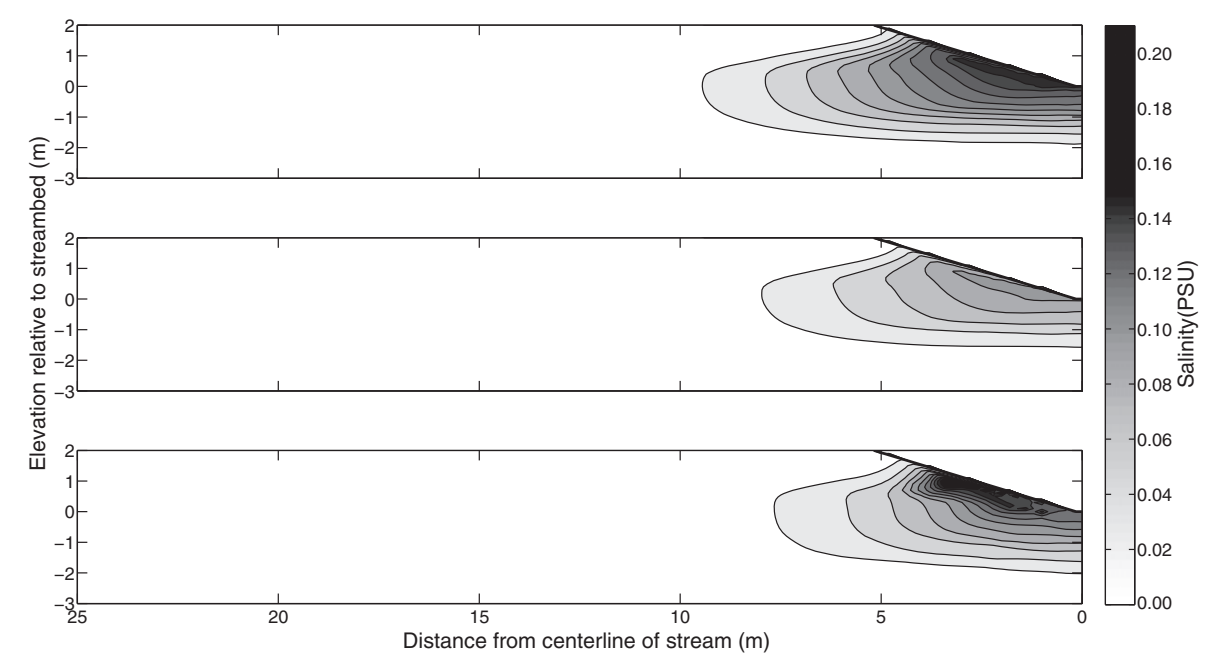

FIGURE 7. Salinity Contours after Five Years of Simulation Time for Base Case (upper panel), Half Salt (middle panel), and Half Stage (lower panel) Simulations. All panels utilize a contour interval of 0.02 for clarity. 
the water table at the height of the highest flood occurrences, such as is seen in the upper saline plumes of subterranean estuaries in coastal aquifers which occur at mean high tide elevations (Robinson et al., 2007). The real effects of reducing stream hydraulics, however, are apparent in comparing salinity contours of the half salt and half stage simulations. The reduced energy of the storm event in the half stage simulations decreased the transport of salt into the riparian aquifer, and as a result, regional flow of freshwater divided the saline plume into two distinct parts, again analogous to the freshwater discharge tube and upper saline plume of coastal aquifers. Because stream stage fluctuations in the half salt simulation were still at their highest levels, the saline plume was not able to leave the aquifer, even with reduced salt in the stream.

Figure 9 shows salinity breakthrough curves for the three cases at monitoring wells MW1, MW3, and MW5 (see Figure 4 for the simulated well locations). The results demonstrate the benefits of reducing stream stage fluctuations, even when continuing to apply road salt, at least in terms of aquifer salinities and chronic salt contamination of baseflow conditions. In the three breakthrough curves shown for MW1, peak concentrations occurred for the base case, as expected. Because of lower stream fluctuations under half stage conditions, even though salinities rose by the fifth year to nearly base case levels, they subsequently responded quickly to the reduced road salt. By year 11 of the simulations, salinities in MW1 for half salt and half stage conditions were equal. At later times, half stage simulations saw slightly lower salinities than the half salt simulations. The reduced energies of the half stage simulations have an even greater influence on the lateral extent of the salinity plume in MW3 and MW5. In MW3, reduced advection of salt into the aquifer produces dramatic declines in salinity such that concentrations in MW3 under half stage conditions equalled those of the half salt conditions after just one year of recovery and continued to fall below them for the rest of the simulation time. At locations further into the aquifer, such as at MW5, the lower energies of the half stage simulations prevented the advection of salt as deeply into the aquifer as the half salt simulations, and as a result, salinities under half stage conditions never reached those of the half salt conditions.

We also performed several sensitivity simulations to better understand the control of hydraulic conductivity and the regional gradient on the distribution of salt in the riparian aquifer while keeping other parameters, such as the boundary conditions, equivalent to the base case simulations. In terms of hydraulic conductivity, values were increased and decreased one order of magnitude from base case levels. Under the higher conductivity scenario, the plume penetrated deeper into the aquifer, but due to increased permeability, the aquifer was able to recover more quickly than under base conditions, with the plume essentially disappearing at stream level within five years of recovery. Conversely, under the lower conductivity scenario, the plume width was less than half that of the base case, and like the base case simulations, this width decreased at a very slow rate during the recovery simulations. The recovery values are less than the base case at all times for the low conductivity scenario, but this is expected because less salt mass has been able to penetrate into the aquifer. The final sensitivity scenario raised the

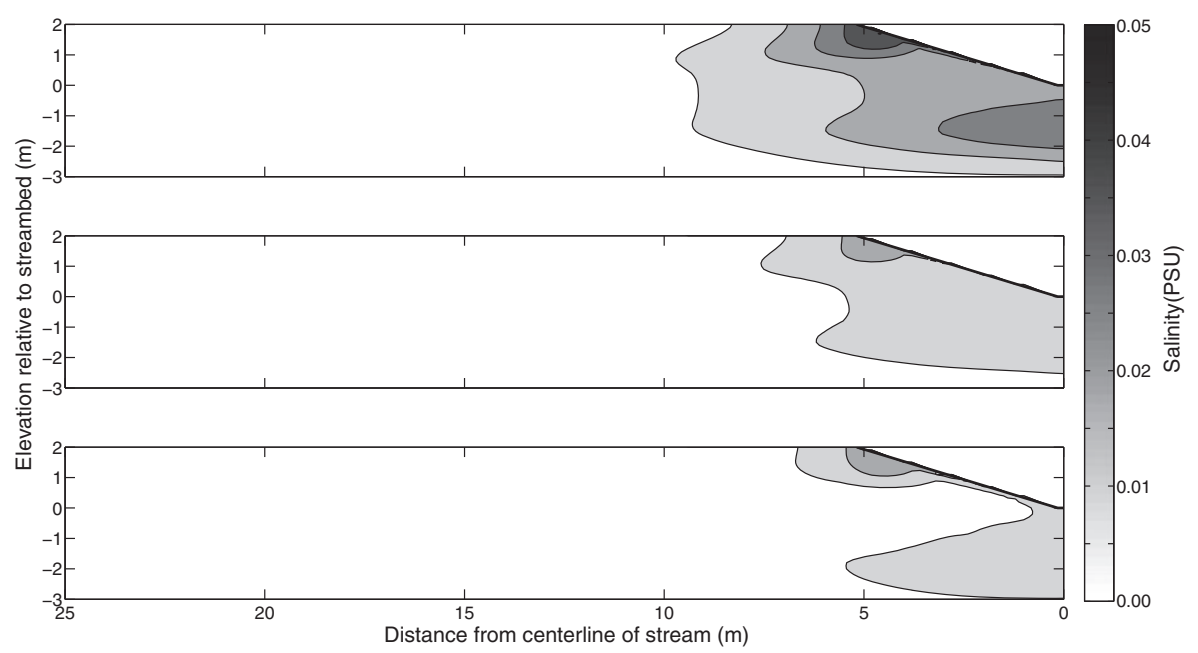

FIGURE 8. Salinity Contours after Five Years of Simulation Time and Ten Years of Recovery Time for Base Case (upper panel), Half Salt (middle panel), and Half Stage (lower panel) Simulations. All panels utilize the same contour intervals for clarity. Note that maximum contour levels in these panels are approximately $25 \%$ of those shown in Figure 7 . The contour interval is 0.01 . 

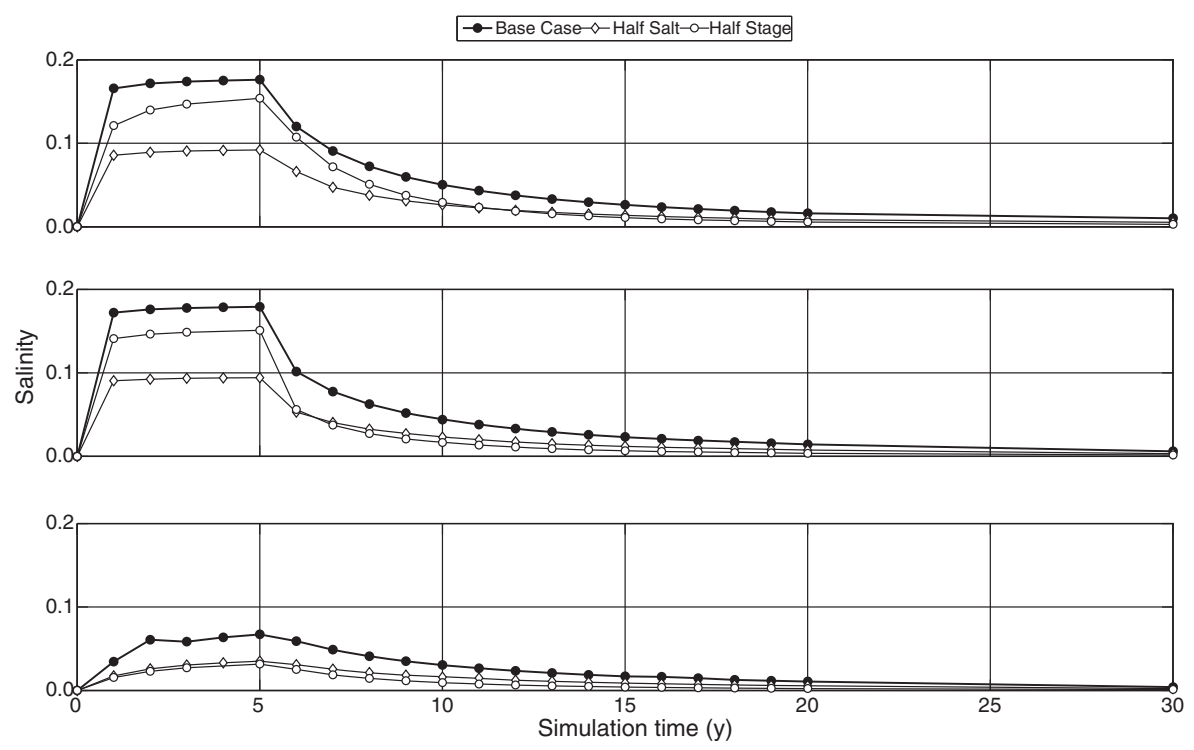

FIGURE 9. Breakthrough Curves of Salinity at Locations Corresponding to the Monitoring Wells MW1 (upper panel), MW3 (middle panel), and MW5 (lower panel) Locations (see Figure 4 for simulated well locations).

regional gradient by a factor of 1.33 . Not unexpectedly, the increased baseflow energy reduced the width of the plume and reduced salinity levels throughout the aquifer relative to base case levels. Additionally, the increased supply of freshwater due to higher regional flow enabled the aquifer to recover much more quickly than under base conditions.

These simple modeling exercises are meant to simulate the effect that unregulated stormwater runoff has on groundwater conditions. In this case, saltladen stormwater runoff not only causes flashy stream conditions, but also forces a portion of those saline waters into the alluvial aquifer. Although groundwater dynamics should allow the saline water to rejoin the surface-water system as baseflow, subsequent summer storms effectively dam the system, keeping the saline water in place and allowing it to build up. This, over time, results in rising baseflow salinities and the possibility of consistently chronic levels, creating a long-term water quality problem for small, urban headwater streams.

\section{Temperature-Surge Modeling}

We used a simple energy balance model to estimate the effects of urbanization on stream temperatures during the storm event of August 11, 2013. Figure 10 shows both the measured stream discharge and temperature time series for the event in addition to baseflow and quickflow discharge rates and temperatures based on the energy-balance model described in the Methods section. We selected this particular storm as a demonstration because of the relatively simple aspects of the event, notably the quick rise and fall of stream discharge without multiple peaks as well as the relatively simple rise and fall of the stream temperature during the event. We should note that this is by no means the largest temperature surge event in Boone Creek, but we think that it provides a strong demonstration of the potential benefits that reducing quickflow can have on stream temperature in response to storm events in urbanized headwater streams.

The storm event began at approximately 08:15 (Figure 10). Prior to the event, stream discharge was approximately $0.0667 \mathrm{~m}^{3} / \mathrm{s}$ and its source was baseflow. By 08:30, however, quickflow began to arrive, and this value peaked at 08:45 when $>90 \%$ of streamflow was contributed by runoff from the urban environment. Stream temperatures began to respond to this heated quickflow and by 09:00 the total amount of the temperature surge reached $5.29^{\circ} \mathrm{C}$. The energybalance model estimates that peak quickflow temperatures did not actually occur until $15 \mathrm{~min}$ after the peak of the flood wave had gone past the temperature monitoring station. The total duration of the quickflow event was 2.5 hours and the stream had recovered to estimated baseflow temperatures by 11:00.

The temperature surge data show in a dramatic fashion the impact that stormwater runoff, in particular heated quickflow, can have on stream water quality. In a simple modeling experiment, we used an energy balance model to estimate the effects on quickflow and corresponding stream temperatures of reducing the ISC in the basin. Figure 11 shows both the quickflow temperatures that would be expected given 10, 30, and 50\% reductions in ISC, and 

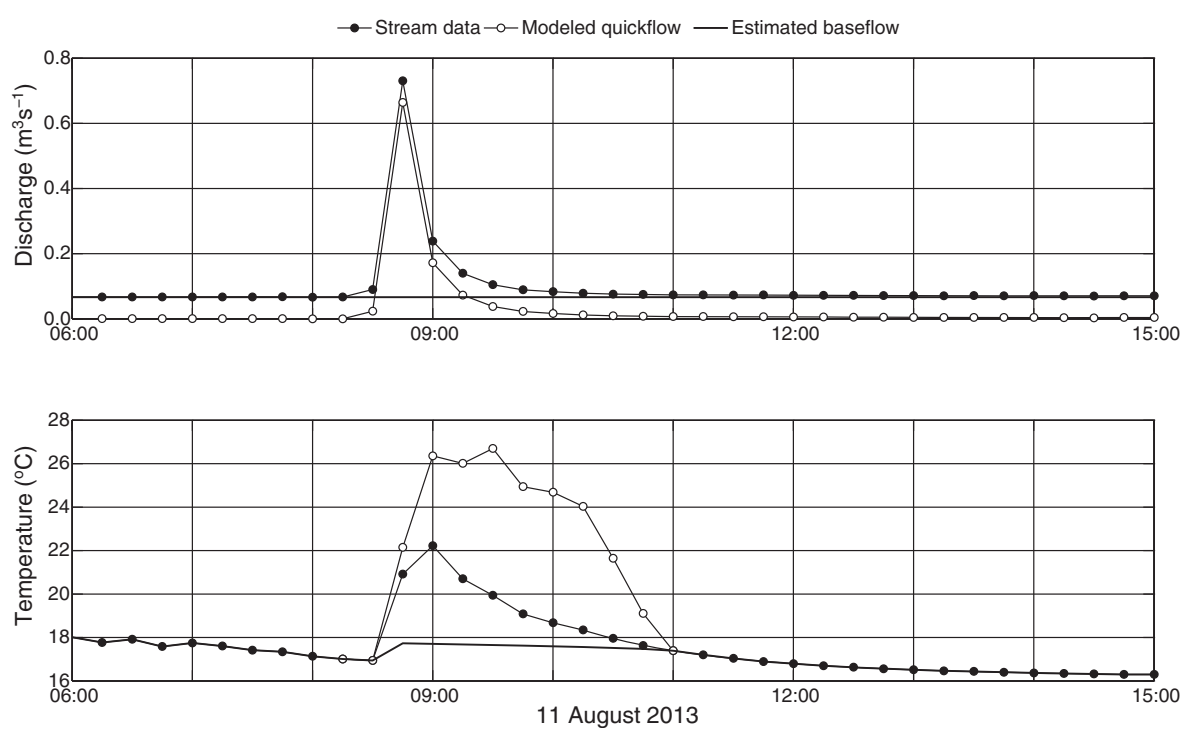

FIGURE 10. The Temperature-Surge Event of August 11, 2013 Is Shown with Discharge Data (upper panel) and Temperature Data (lower panel). The panels also show estimated quickflow and baseflow discharge rates and temperatures based on model output.

correspondingly, reductions in stream temperatures. For the purposes of this simple demonstration, we converted the reduced areas to open ground as a proxy for nonspecific stormwater BMPs designed to lower runoff temperatures. We assigned the corresponding region's air temperatures as described in the Methods section. It should be noted that in these simple calculations, the total amount of quickflow was not changed, but the weighted temperatures changed due to reduced ISC. Figure 11 shows the effects of reducing ISC. Peak quickflow temperatures not only dropped by $3.15^{\circ} \mathrm{C}$ in the $50 \%$ reduction scenario, but the timing of the peak temperature arrival moved $30 \mathrm{~min}$ earlier than the initial calculations, which showed peak temperatures arriving one hour after the onset of runoff. We used these revised quickflow temperatures to recalculate expected stream temperatures under the proposed new conditions (Figure 11). As expected, lower quickflow temperatures resulted in lower temperature surges with a maximum decline under the $50 \%$ ISC reduction scenario of $1.22^{\circ} \mathrm{C}$.

Reducing the amount of quickflow, which was done in the second set of simulations, has a more dramatic effect on resulting stream temperatures. Figure 12 shows quickflow reductions and modeled stream temperatures. Again, these simple simulations show the effectiveness that reducing quickflow could have on temperature surge dynamics. The maximum reduction used in these calculations was $25 \%$; however, the timing of peak quickflow did not occur at the same time as the maximum quickflow temperatures, and the combined effects caused a reduced peak temperature during the surge of $3.44^{\circ} \mathrm{C}$ between measured data and modeled 25\% reductions. For the modeled storm, the $25 \%$ quickflow reduction had the added benefit of keeping the temperature surge below the $20^{\circ} \mathrm{C}$ threshold. Likewise, the lower quickflow reduction scenarios suggest that the effects of stream temperature surges may be reduced with modest levels of stormwater management (e.g., any method that reduces quickflow by $15 \%$ ), whether that be bioretention systems, pervious pavement, cisterns, or other management approaches. Again, this demonstration model was not meant to justify a particular type of BMP, but instead to demonstrate the effects that reduced quickflow can have on temperature surge timing and magnitude.

\section{DISCUSSION}

\section{Modeling}

Solutes (in this case road salt) and energy (heat) carried by stormwater runoff, or quickflow, present a serious water-quality issue in urbanized streams. The simple models used in this study are just that: simple demonstrations of how reducing quickflow may affect water quality in urbanized streams. Because contemporary stormwater management techniques (e.g., rain gardens, cisterns, permeable pavement) focus on slowing water flow to streams, the reduced quickflow simulations offer insight into the positive impact these techniques might have. The models are not intended to assess any specific stormwater 

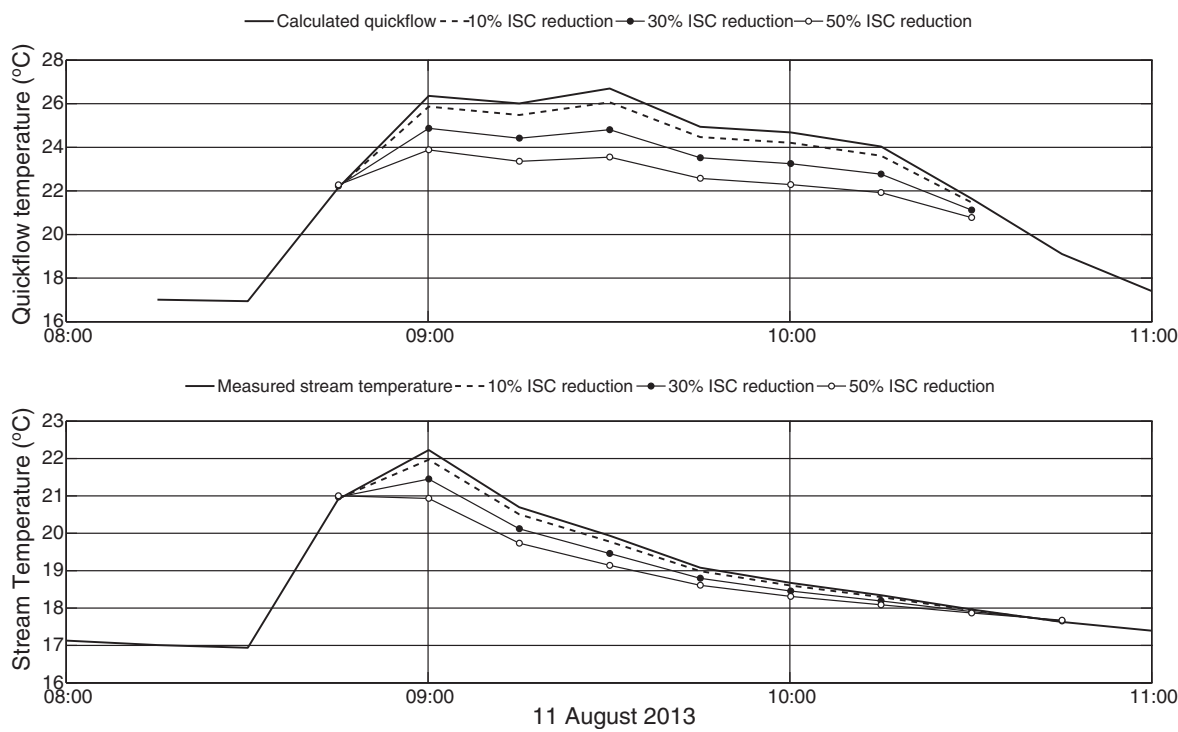

FIGURE 11. Plots of Reduced Quickflow Temperatures (upper panel) and Resulting Stream Temperatures (lower panel) under the Assumption that ISC Areas Are Reduced as Indicated. The calculations are for the August 11, 2013 temperature-surge event.
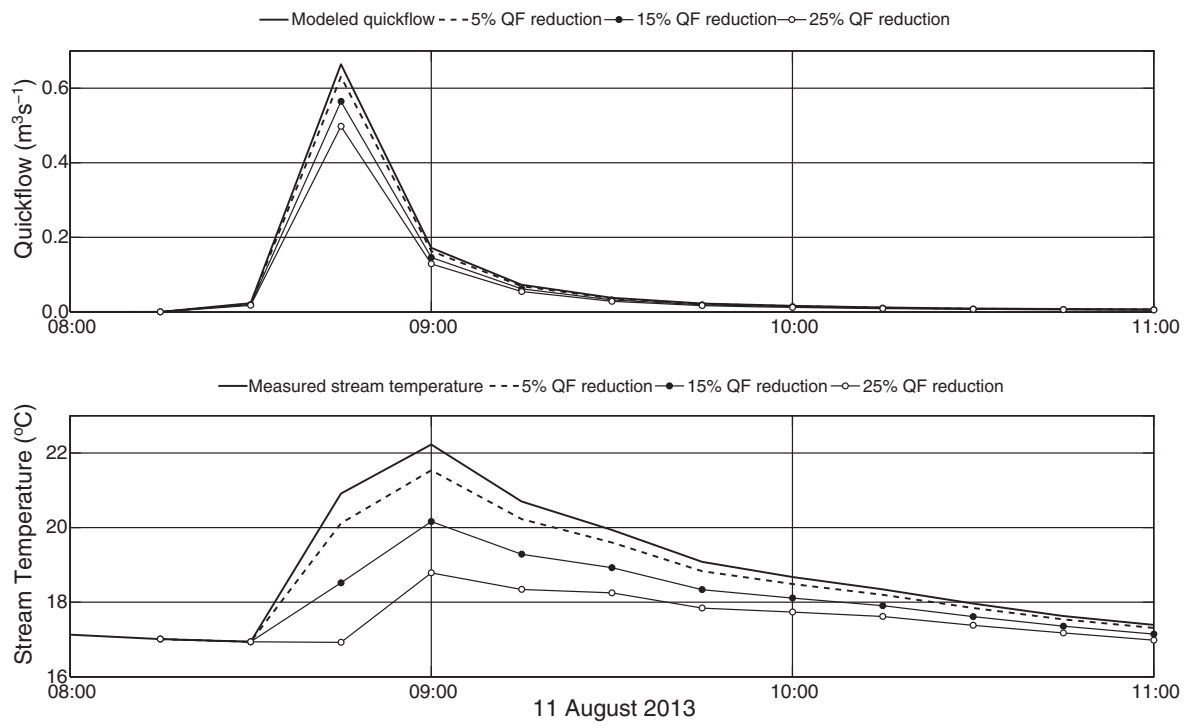

FIGURE 12. Plots of Reduced Quickflow Discharges (upper panel) and Resulting Stream Temperatures (lower panel) under the Assumption that Quickflow Rates Are Reduced but Not Lowered in Temperature. The calculations are for the August 11, 2013 temperature-surge event.

management practices and deciding which practices might be best depends not only on place specific hydrologic data, but on social, economic, and political realities as well. What our models do show is that a variety of appropriately placed and well-managed techniques that reduce quickflow could simultaneously reduce salinity and thermal pollution from stormwater runoff.

In addition to salinity and temperature concerns, runoff also influences groundwater-surface-water interactions. The salt-transport modeling demonstrated that alluvial aquifers connected to gaining streams through baseflow can become temporarily losing streams during storm events, and the result can be solute transport into the aquifer. Because these reversed-gradient events tend to occur frequently in this urbanized headwater stream (Figure 5), there are many opportunities for contamination. In addition, our monitoring data show high saline levels in summer as well as winter, supporting model results indicating that reversed-gradient events occur year-round, with nonwinter events driving saline water further into the aquifer, effectively damming groundwater flow and greatly 
increasing contaminant residence times. Unlike heat contamination, which dissipates with time, salt contamination as chloride is a conservative solute and remains in the system until transported out of the system. In the case of Boone Creek, baseflow salinities continue to rise annually because of this dynamic (Cockerill and Anderson, 2014; F.T. Shepherd, 2016, unpublished thesis). As the recovery simulations show, stormwater management that reduces stage also reduces advective transport into the aquifer, thereby reducing residence time and baseflow salinities.

The temperature-surge modeling demonstrated that runoff management can be an important aspect of maintaining reasonable stream temperatures. The energy-balance model we utilized is admittedly simplified: we do not include solar insolation in the calculations and instead calculate the quickflow temperatures based on the weighted mixing of stream water, groundwater, and quickflow discharge. We do not think that the omission of solar radiation has an overwhelming effect over the course of our short sample storm event. In fact, we think the quickflow temperatures calculated by the mixing model are reasonable and fall below estimates in the literature of over $30^{\circ} \mathrm{C}$ (Herb et al., 2008; Janke et al., 2009).

\section{Management Implications}

Our results confirm previous work showing chloride concentrations increasing in U.S. streams, revealing that high salt levels are not limited to winter months, and suggesting long-term implications for stream quality (Perera et al., 2013; Corsi et al., 2015). To this knowledge base we contribute a more robust understanding of the fate of salt in a streamgroundwater system and the potential for reducing quickflow to ameliorate temperature surges and salt concentrations. The modeled quickflow reductions serve as a proxy for implementing stormwater management practices in a watershed.

An important lesson from our simulations is that if any salt enters the system, there is a long-term effect; salinity levels will likely remain elevated for years. As our model demonstrates and others have noted (Corsi et al., 2015), the best scenario for reducing impacts of salt in a water system is to eliminate salt use as a de-icing agent. In our case (and likely in most cases where salt is used for de-icing), this would be a popular option with university physical plant and the Town of Boone utilities because salt is expensive and requires employee labor to distribute. Additionally, the salt is highly corrosive to campus and town infrastructure and eliminating salt use would reduce maintenance costs. Eliminating salt use in our study area, however, is highly improbable because the region averages $>1 \mathrm{~m}$ of snow per year and has numerous icing events each winter. Almost $70 \%$ of ASU students live off campus and much of the offcampus housing is not walkable (e.g., no sidewalks, several $\mathrm{km}$ from campus). These students either drive or ride a bus to campus. Additionally, the majority of faculty and staff do not live within the Town of Boone where the university is located and therefore must drive to campus (Appalachian State University, Institutional Research, Assessment and Planning Office, response to email request, 2015). Although we do not have similar data for the Town of Boone employees, the cost of living in town is high and therefore, many people live outside the city limits, necessitating driving to work in the winter. This is a mountainous region, with steep, narrow, winding roads that do require significant management to remain drivable in the winter.

Informal conversations with university physical plant employees suggested that when roads and sidewalks on campus are not completely ice and snow free, faculty and staff complain. We hypothesize that one contributing factor is a cultural norm about perceived safety and what level of snow or ice removal is necessary. University and town employees who have lived at lower altitudes or in warmer climates and have had no experience in living with winter conditions may have more serious concerns about driving and walking in snow or ice, and hence expect more intense removal efforts. Conversely, individuals from more northerly regions may be more comfortable with less intense clearing actions because they have more experience walking and driving in snowy or icy conditions. Further, the university does have liability concerns for employee and student safety. Additionally, the local topography is a relevant factor. The highgradient landscape does mean that slick conditions may pose a greater risk than slick conditions in a flat terrain. Together, these variables all influence the amount of salt used to keep sidewalks and roads clear of snow and ice. These or similar social and economic concerns are relevant to any urban area that experiences winter conditions.

As with eliminating salt entirely, reducing the amount of salt has positive economic and water quality impacts, but the $50 \%$ reduction we modeled may not be realistic given safety concerns and public perception. Finding an optimal parameter for salt application that ensures safety, avoids complaints, and reduces impacts on water quality is something the campus and town could explore. For example, there are likely options for doing more manual snow removal and reducing the amount of salt applied as well as doing more targeted salting of primary walkways rather than the wholesale salt coverage that is 
currently employed. This, of course, would require a cost-benefit analysis to assess the tradeoffs among salt use, labor costs, and potential liability issues. Such an analysis is beyond the scope of this article.

Removing salt from the system would be effective, but our model results show that reducing the rate at which stormwater runs off into waterways can be equally effective. Again, this suggests that implementing a mix of stormwater management practices appropriate to a particular place to hold and slow runoff before it enters streams may effectively address both salinity and temperature surges. Of course, slowing the water down does not change the total amount of salt available, it simply redistributes it in the watershed and pushes it downstream in a more dilute form. Dilution does, however, lower the acute salinity concern and likely the chronic concern as well. Reducing quickflow with stormwater management measures can eliminate temperature surges because temperature does dissipate as the rate of flow to the stream is slowed. Implementing stormwater management features to reduce the salt impact would therefore, simultaneously ameliorate the temperature issue.

While our model suggests that stormwater management efforts designed to reduce quickflow in a particular place could potentially improve stream conditions, actually implementing such practices is complicated. Stormwater runoff is entirely indifferent to property jurisdiction. It does not know or care if it is running off campus property, town property, or private property. To achieve the modeled results in this study area would require action throughout the watershed. Any singular action (e.g., one rain garden, or one parking lot with permeable pavement) would be positive, but not at the scale required to see improvement in stream water quality. For example, our modeled temperature surge scenario would require storing approximately $820 \mathrm{~m}^{3}$ from that portion of the basin for that storm, which is approximately 218,000 gallons. This could be accomplished with a single retention pond of approximately $235 \mathrm{~m}^{2}$ and $3.5 \mathrm{~m}$ deep or with multiple smaller retention ponds scattered throughout the basin. While many urban areas may face difficulty in siting large-scale retention systems, in this study area, the steep terrain introduces an additional layer of difficulty both because of gravity, making an "ideal" collection point difficult to ascertain, and because relatively flat property available for campus or town development is at an economic premium. Therefore, a decentralized approach is potentially more feasible. It would also potentially be more effective in reducing impacts from both salinity and temperature because it would offer better shading and more opportunities for enhanced infiltration across the multiple sites. A decentralized system, however, requires both the campus and the town and potentially private landowners to participate in stormwater management practices. Again, such jurisdictional siting issues are not unique to our case, but would apply in many urban settings.

To return to our initial research questions, we find that in this study area, groundwater-surface water relationships are complex and that a reversed gradient during storm events basically dams the system, pushing salty water into the alluvial aquifer. As the stream reacquires baseflow from the system, the salty water returns to the surface, explaining the elevated salt levels in summer months. Our model suggests that reducing salt application would be effective in reducing salt spikes and lowering the long-term salt levels, but that reducing quickflow is equally effective. Any stormwater management practice that reduced quickflow should reduce both salt and temperature surges.

Our work highlights the complexity in thinking about urban impacts on streams and that there is no singular approach that is likely to reduce impacts in all cases. For regions with winter conditions, for example, using road salt will likely have long-term consequences, but how and when those consequences manifest is dependent on the water dynamics of that place. What our model does suggest is that planners and managers do have options. In cold climates, for example, implementing stormwater management is potentially more feasible than eliminating or even reducing salt use. While the specific conditions of any urban stream will differ, our model suggests that planners and managers can have confidence that if they can find ways to implement stormwater management practices to reduce quickflow, these efforts should have positive impacts on local waterways, at least related to salt and temperature.

\section{ACKNOWLEDGMENTS}

The authors thank the Department of Geology, the College of Arts and Sciences, and the Office of Student Research at Appalachian State University for supporting a portion of this work. Author Anderson thanks a number of undergraduate research assistants who over the past decade have helped to maintain the stream monitoring network: Joseph Anderson, Joshua Rice, Garrett Thompson, Forest Shepherd, Emily Fedders, Cole Thompson, Jacob Schenk, Jacob Shearer, Andrew Burgess, and co-authors Claire Harris and Kelli Straka. Finally, we acknowledge the feedback from the anonymous reviewers whose input greatly improved this article.

\section{LITERATURE CITED}

Ahiablame, L.M., B.A. Engel, and I. Chaubey, 2012. Effectiveness of Low Impact Development Practices: Literature Review and 
Suggestions for Future Research. Water Air Soil Pollution 223 (7):4253-4273, DOI: $10.1007 / \mathrm{s} 11270-012-1189-2$.

Anderson, Jr., W.P., J.L. Anderson, C.S. Thaxton, and C.M. Babyak, 2010. Changes in Stream Temperatures in Response to Restoration of Groundwater Discharge and Solar Heating in a Culverted, Urban Stream. Journal of Hydrology 393(3-4):309320, DOI: 10.1016/j.jhydrol.2010.08.030.

Anderson, Jr., W.P., C.M. Babyak, and C.S. Thaxton, 2007. Baseline Monitoring Case Study of a High-Gradient Urbanized Stream: Boone Creek, Boone, NC. In: Proceedings of the 2nd National Low Impact Development Conference, Wilmington, North Carolina.

Anderson, Jr., W.P., R.E. Storniolo, and J.S. Rice, 2011. Bank Thermal Storage as a Sink of Temperature Surges in Urbanized Streams. Journal of Hydrology 409(1-2):525-537, DOI: 10.1016/j. jhydrol.2011.08.059.

Booth, D.B., J.R. Karr, S. Schauman, C.P. Konrad, S.A. Morley, M.G. Larson, and S.J. Burges, 2004. Reviving Urban Streams: Land Use, Hydrology, Biology and Human Behavior. Journal of the American Water Resources Association 40(5):1351-1364, DOI: $10.1111 /$ j.1752-1688.2004.tb01591.x.

Brabec, E., S. Schulte, and P.L. Richards, 2002. Impervious Surfaces and Water Quality: A Review of Current Literature and Its Implications for Watershed Planning. Journal of Planning Literature 16(4):499-514.

Brown, L.R., T.F. Cuffney, J.F. Coles, F.A. Fitzpatrick, G. McMahon, J. Steuer, A.H. Bell, and J.T. May, 2009. Urban Streams across the USA: Lessons Learned from Studies in Nine Metropolitan Areas. Journal of the North American Benthological Society 28(4):1051-1069.

Burns, M.J., C.J. Walsh, T.D. Fletcher, A.R. Ladson, and B.E. Hatt, 2015. A Landscape Measure of Urban Stormwater Runoff Effects Is a Better Predictor of Stream Condition than a Suite of Hydrologic Factors. Ecyhydrology 8:160-171, DOI: 10.1002/eco. 1497.

Caissie, D., 2003. The Thermal Regime of Rivers: A Review. Freshwater Biology 51(8):1389-1406, DOI: 10.1111/j.1365-2427.2006. 01597.x.

Chadwick, Jr., J.G., K.H. Nislow, and S.D. McCormick, 2015. Thermal Onset of Cellular and Endocrine Stress Responses Correspond to Ecological Limits in Brook Trout, an Iconic Cold-Water Fish. Conservation Physiology 3(1):Cov017, DOI: 10.1093/con phys/cov017.

Christian-Smith, J. and A.M. Merenlender, 2010. The Disconnect between Restoration Goals and Practices: A Case Study of Watershed Restoration in the Russian River Basin, California. Restoration Ecology 18(1):95-102, DOI: 10.1111/j.1526-100X. 2008.00428.x.

Cockerill, K. and W.P. Anderson, Jr., 2014. Creating False Images: Stream Restoration in an Urban Setting. Journal of the American Water Resources Association 50(2):468-482, DOI: 10.1111/ jawr.12131.

Coles, J.F., G. McMahon, A.H. Bell, L.R. Brown, F.A. Fitzpatrick, B.C.S. Eikenberry, M.D. Woodside, T.F. Cuffney, W.L. Bryant, K. Cappiella, L. Fraley-McNeal, and W.P. Stack, 2012. Effects of Urban Development on Stream Ecosystems in Nine Metropolitan Study Areas across the United States. U.S. Geological Survey Circular 1371, 152 pp. https://pubs.usgs.gov/circ/ 1373/pdf/Circular1373.pdf.

Conrads, P.A., E.A. Roehl, Jr., and S.R. Davie, 2011. Simulation of Specific Conductance and Chloride Concentration in Abercorn Creek, Georgia, 2000-2009. U.S. Geological Survey Scientific Investigations Report 2011-5074, 46 pp. https://pubs.usgs.gov/ sir/2011/5074/pdf/sir2011-5074.pdf.

Cooper, C.A., P.M. Mayer, and B.R. Faulkner, 2014. Effects of Road Salts on Groundwater and Surface Water Dynamics of Sodium and Chloride in an Urban Restored Stream. Biogeochemistry 121(1):149-166, DOI: 10.1007/s10533-014-9968-z.

Corsi, S.R., L.A. De Cicco, M.A. Lutz, and R.M. Hirsch, 2015. River Chloride Trends in Snow-Affected Urban Watersheds: Increasing Concentrations Outpace Urban Growth Rate and Are Common Among All Seasons. Science of the Total Environment 508 (March):488-497.

Daley, M.L., J.D. Potter, and W.H. McDowell, 2009. Salinization of Urbanizing New Hampshire Streams and Groundwater: Effects of Road Salt and Hydrologic Variability. Journal of the North American Benthological Society 28(4):929-940.

Endreny, T., D.J. Burke, K.M. Burchhardt, M.W. Fabian, and A.M. Kretzer, 2012. Bioretention Column Study of Bacteria Community Response to Salt-Enriched Artificial Stormwater. Journal of Environmental Quality 41(6):1951-1959, DOI: 10.2134/jeq2012. 0082.

Fitzgerald, E.P., W.B. Bowden, S.P. Parker, and M.L. Kline, 2012. Urban Impacts on Streams Are Scale-Dependent with Nonlinear Influences on Their Physical and Biotic Recovery in Vermont, United States. Journal of the American Water Resources Association 48(4):679-697, DOI: 10.1111/j.1752-1688.2012.00639.x.

Fofonoff, N.P. and R.C. Millard, Jr., 1983. Algorithms for Computation of Fundamental Properties of Seawater. UNESCO Technical Papers in Marine Science 44, 53 pp. http://unesdoc.unesco. org/images/0005/000598/059832eb.pdf, accessed April 2017.

Halstead, J.A., S. Kliman, C.W. Berhelde, and A. Chaucer, 2014. Urban Stream Syndrome in a Small, Lightly Developed Watershed: A Statistical Analysis of Water Chemistry Parameters, Land Use Patterns, and Natural Sources. Environmental Monitoring and Assessment 186(6):3391-3414, DOI: 10.1007/s10661014-3625-9.

Hamel, P., E. Daly, and T.D. Fletcher, 2013. Source-Control Stormwater Management for Mitigating the Impacts of Urbanisation on Baseflow: A Review. Journal of Hydrology 485:201211, DOI: 10.1016/j.jhydrol.2013.01.001.

Herb, W.R., B. Janke, O. Mohseni, and H.G. Stefan, 2008. Thermal Pollution of Streams by Runoff from Paved Surfaces. Hydrological Processes 22(7):987-999, DOI: 10.1002/hyp.6986.

Janke, B., W.R. Herb, O. Mohseni, and H.G. Stefan, 2009. Simulation of Heat Export by Rainfall-Runoff from a Paved Surface. Journal of Hydrology 365(3-4):195-212, DOI: 10.1016/j.jhydrol. 2008.11.019.

Jones, M.P., W.F. Hunt, and R.J. Winston, 2012. Effect of Urban Catchment Composition on Runoff Temperature. Journal of Environmental Engineering 138(12):1231-1236.

Kaushal, S., P.M. Groffman, G.E. Likens, K.T. Belt, W.P. Stack, V.R. Kelly, L.E. Band, and G.T. Fisher, 2005. Increased Salinization of Fresh Water in the Northesastern United States. PNAS 102(38):13517-13520, DOI: 10.1073/pnas.0506414102.

Khan, U.T., C. Valeo, A. Chu, and B.V. Duin, 2012. Bioretention Cell Efficacy in Cold Climates: Part 2 - Water Quality Performance. Canadian Journal of Civil Engineering 39(11):1222-1233.

Liu, G., F.W. Schwartz, and Y. Kim, 2013. Complex Baseflow in Urban Streams: An Example from Central Ohio, USA. Environmental Earth Sciences 70(7):3005-3014, DOI: 10.1007/s12665013-2358-3.

Loperfido, J.V., G.B. Noe, S.T. Jarnagin, and D.M. Hogan, 2014. Effects of Distributed and Centralized Stormwater Best Management Practices and Land Cover on Urban Stream Hydrology at the Catchment Scale. Journal of Hydrology 519(Part C):25842595, DOI: 10.1016/j.jhydrol.2014.07.007.

Meyer, J.L., M.J. Paul, and W.K. Taulbee, 2005. Stream Ecosystem Function in Urbanizing Landscapes. Journal of the North American Benthological Society 24(3):602-612, DOI: 10.1899/04-021.1.

NCDEQ (North Carolina Department of Environmental Quality), 2016. Classifications and Standards. http://deq.nc.gov/about/d 
ivisions/water-resources/planning/classification-standards/classif ications\#DWRPrimaryClassification, accessed April 2017.

Nelson, K.C. and M.A. Palmer, 2007. Stream Temperature Surges under Urbanization and Climate Change: Data, Models, and Responses. Journal of the American Water Resources Association 43(2):440-452, DOI: 10.1111/j.1752-1688.2007.00034.x.

North Carolina Geological Survey, 1985. Geologic Map of North Carolina. P.M. Brown, Chief Geologist, J.M. Parker, III, State Geologic Map Coordinator, 1 plate.

O'Driscoll, M., S. Clinton, A. Jefferson, A. Manda, and S. McMillan, 2010. Urbanization Effects on Watershed Hydrology and InStream Processes in the Southern United States. Water 2 (3):605-648, DOI: $10.3390 / w 2030605$.

Palmer, M.A., H.L. Menninger, and E.S. Bernhardt, 2010. River Restoration, Habitat Heterogenity and Biodiversity: A Failure of Theory or Practice. Freshwater Biology 55(1):202-222, DOI: 10. 1111/j.1365-2427.2009.02372.x.

Perera, N., B. Gharabaghi, and K. Howard, 2013. Groundwater Chloride Response in the Highland Creek Watershed Due to Road Salt Application: A Re-assessment after 20 Years. Journal of Hydrology 479:159-168, DOI: 10.1016/j.jhydrol.2012.11.057.

Perera, N., B. Gharabaghi, P. Noehammer, and B. Kilgour, 2010. Road Salt Application in Highland Creek Watershed, Toronto, Ontario - Chloride Mass Balance. Water Quality Research Journal of Canada 45(4):451-461.

Price, K., 2011. Effects of Watershed Topography, Soils, Land Use, and Climate on Baseflow Hydrology in Human Regions: A Review. Progress in Physical Geography 35(4):465-492, DOI: 10. 1177/0309133311402714.

Quigley, J.T. and S.G. Hinch, 2006. Effects of Rapid Experimental Temperature Increases on Acute Physiological Stress and Behaviour of Stream Dwelling Juvenile Chinook Salmon. Journal of Thermal Biology 31(5):429-441, DOI: 10.1016/j.jtherbio.2006.02. 003.

Ramirez, A., R.D. Jesus-Crespo, D.M. Martino-Cardona, N. Martinez-Rivera, and S. Burgos-Caraballo, 2009. Urban Streams in Puerto Rico: What Can We Learn from the Tropics? Journal of the North American Benthological Society 28(4):1070-1079, DOI: $10.1899 / 08-165.1$.

Rice, J.S., W.P. Anderson, Jr., and C.S. Thaxton, 2011. Urbanization Influences on Stream Temperature Behavior within LowDischarge Headwater Streams. Hydrological Research Letters 5:27-31, DOI: 10.3178/hrl.5.27.

Robinson, C., L. Li, and D.A. Barry, 2007. Effect of Tidal Forcing on a Subterranean Estuary. Advances in Water Resources 30 (4):851-865, DOI: 10.1016/j.advwatres.2006.07.006.

Sarwar, A. and H. Eggers, 2006. Development of a Conjunctive Use Model to Evaluate Alternative Management Options for Surface and Groundwater Resources. Hydrogeology Journal 14(8):16761687, DOI: 10.1007/s10040-006-0066-8.

Shepherd, F.T., 2016. Stream Salt Concentration Dynamics in a Southern Appalachian Urban Watershed. Senior Honors Thesis (unpublished), Appalachian State University, Department of Geology, 38 pp.

Sloto, R.A. and M.Y. Crouse, 1996. HYSEP: A Computer Program for Streamflow Hydrograph Separation and Analysis. U.S. Geological Survey Water-Resources Investigations Report 96-4040, 46 pp. https://water.usgs.gov/software/HYSEP/code/doc/hysep.pdf.

Smith, B., N.J. Clifford, and J. Mant, 2013. Analysis of UK River Restoration Using Broad-Scale Data Sets. Water and Environment Journal 28(4):490-501, DOI: 10.1111/wej.12063.

Soberg, L.C., M. Viklander, and G.-T. Blecken, 2014. The Influence of Temperature and Salt on Metal and Sediment Removal in Stormwater Biofilters. Water, Science \& Technology 69 (11):2295-2304, DOI: 10.2166/wst.2014.161.

Sudduth, E.B., B.A. Hassett, P. Cada, and E.S. Bernhardt, 2011. Testing the Field of Dreams Hypothesis: Functional Responses to Urbanization and Restoration in Stream Ecosystems. Ecological Applications 21(6):1972-1988.

Thaxton, C.S. and K. Cockerill, 2007. Water Resources Planning Committee Report: Assessment and Recommendations for Boone Creek and University Policy Regarding Impact on Water Resources, 52 pp. http://pimlico.phys.appstate.edu/WRPC/ WRPC_Policy_Recommendations.pdf, accessed April 2017.

USEPA (U.S. Environmental Protection Agency), 1988. Ambient Water Quality Criteria for Chloride - 1988. USEPA-440/5-88001. USEPA, Washington, D.C., 47 pp.

USEPA (U.S. Environmental Protection Agency), 2003. EPA Issues Final Water Temperature Guidance - April 2003, 2 pp. http:// www3.epa.gov/region10/pdf/water/temperature_standards_fs.pdf, accessed April 2017.

Violin, C.R., P. Cada, E.B. Sudduth, B.A. Hassett, D.L. Penrose, and E.S. Bernhardt, 2011. Effects of Urbanization and Urban Stream Restoration on the Physical and Biological Structure of Stream Ecosystems. Ecological Applications 21(6):1932-1949.

Walsh, C.J., A.H. Roy, J.W. Feminella, P.D. Cottingham, P.M. Groffman, and R.P.I. Morgan, 2005. The Urban Stream Syndrome: Current Knowledge and the Search for a Cure. Journal of the North American Benthological Society 24(3):706-723, DOI: $10.1899 / 04-028.1$.

Wang, L. and P. Kanehl, 2003. Influences of Watershed Urbanization and Instream Habitat on Macroinvertebrates in Cold Water Streams. Journal of the American Water Resources Association 39(5):1181-1196, DOI: 10.1111/j.1752-1688.2003.tb03701.x.

Wang, L., J. Lyons, and P. Kanehl, 2003. Impacts of Urban Land Cover on Trout Streams in Wisconsin and Minnesota. Transactions of the American Fisheries Society 132(5):825-839, DOI: 10. 1577/T02-099.

Wang, S., W.P. Anderson, Jr., and L.A. Raymond, 2014. Hydrogeology and Water Quality at the Tater Hill Groundwater Monitoring and Research Station, Watauga County, North Carolina. North Carolina Department of Environment and Natural Resources - Division of Water Quality, Groundwater Bulletin 2014-01, 55 pp. http://cdm16062.contentdm.oclc.org/cdm/ref/col lection/p16062coll9/id/240412, accessed April 2017.

Wardynski, B.J., R.J. Winston, and W.F. Hunt, 2013. Internal Water Storage Enhances Exfiltration and Thermal Load Reduction from Permeable Pavement in the North Carolina Mountains. Journal of Environmental Engineering 139(2):187-195, DOI: 10.1061(ASCE)EE,1943-7870.0000626.

Wenger, S.J., A.H. Roy, C.R. Jackson, E.S. Bernhardt, T.L. Carter, S. Filoso, C.A. Gibson, W.C. Hession, S.S. Kaushal, E. Marti, J.L. Meyer, M.A. Palmer, M.J. Paul, A.H. Purcell, A. Ramirez, A.D. Rosemond, K.A. Schofield, E.B. Sudduth, and C.J. Walsh, 2009. Twenty-Six Key Research Questions in Urban Stream Ecology: An Assessment of the State of the Science. Journal of the North American Benthological Society 28(4):1080-1098, DOI: $10.1899 / 08-186.1$

Windsor, C., A. Steinbach, and A.E. Lockwood, 2011. Verifying the Use of Specific Conductance as a Surrogate for Chloride in Seawater Matrices. In-Situ, Inc., 7 pp.

Wohl, E., S.N. Lane, and A.C. Wilcox, 2015. The Science and Practice of River Restoration. Water Resources Research 51(8):59745997, DOI: 10.1002/2014WR016874.

Yechieli, Y., U. Kafri, S. Wollman, E. Shalev, and V. Lyakhovsky, 2009. The Effect of Base Level Changes and Geological Structures on the Location of the Groundwater Divide, as Exhibited in the Hydrological System between the Dead Sea and the Mediterranean Sea. Journal of Hydrology 378(3-4):218-229, DOI: $10.1016 /$ j.jhydrol.2009.09.023.

Yocom, K., 2014. Building Watershed Narratives: An Approach for Broadening the Scope of Success in Urban Stream Restoration. Landscape Research 39(6):698-714, DOI: 10.1080/01426397. 2014.947249. 